\title{
Germinação de embriões e crescimento inicial in vitro de macaúba
}

\author{
Germination and early growth of embryos of macaúba seedlings
}

\section{Joyce Dória Rodrigues Soares ${ }^{{ }^{*}}$ Filipe Almendagna Rodrigues $^{\mathrm{I}}$ Moacir Pasqual ${ }^{\mathrm{I}}$ Claudinéia Ferreira Nunes ${ }^{\mathbb{I}}$ Aparecida Gomes de Araujo ${ }^{\mathbb{I}}$}

RESUMO

\begin{abstract}
A macaúba é uma palmeira oleaginosa altamente produtiva e seu óleo pode ser usado na produção de biocombustíveis. $O$ presente trabalho teve como objetivos avaliar a influência de concentrações dos sais do meio de cultura MS e de água de coco na germinação in vitro de embrióes zigóticos de macaúba e no crescimento inicial de plântulas. Os embrióes foram excisados e em seguida inoculados em tubos de ensaio contendo $15 \mathrm{~mL}$ de meio de cultura MS nas concentrações de 50 e $100 \%$ de sais minerais, acrescidos de água de coco $\left(0,50,100\right.$ e $\left.150 \mathrm{~mL} \mathrm{~L}^{-1}\right)$. As culturas foram mantidas em sala de crescimento com irradiância em torno de $42 \mathrm{~W} \mathrm{~m}^{-2}$, temperatura de $25 \pm 2^{\circ} \mathrm{C} e$ fotoperíodo de 16 horas. Maior porcentagem de germinação de embriões de macaúba foi obtida aos 60 dias, em meio MS, na concentração original dos sais. O crescimento e a conversão de plântulas viáveis ou normais, passíveis de serem aclimatizadas, requerem metade da concentração de sais do meio MS suplementado com 50mL $L^{-1}$ de água de coco.
\end{abstract}

Palavras-chave: meio MS, água de coco, cultura de embriões, biocombustível, palmeira, Acrocomia aculeata.

\section{ABSTRACT}

The macaw is a palm oleaginous that it is highly productive and in which their oil can be used to produce biofuels.This study aimed to evaluate the influence of concentrations of minerals of the culture medium MS and coconut water germination in vitro of zygotic embryos of macaw and initial growth of seedlings. The embryos were inoculated in test tubes containing $15 \mathrm{~mL}$ of culture medium $M S$ in concentrations of 50 and $100 \%$ of minerals, plus coconut water $\left(0,50,100\right.$ and $\left.150 \mathrm{~mL} \mathrm{~L} \mathrm{~L}^{-1}\right)$. The cultures were kept in room for growth with irradiance around $42 \mathrm{~W} \mathrm{~m}^{-2}$, at $25 \pm 2{ }^{\circ} \mathrm{C}$ and photoperiod of 16 hours. Higher percentage of germination of embryos of 'macaúba' was obtained at 60 days in MS medium in the original concentration of salts. The growth and conversion to viable seedlings or normal, which can be acclimatized, require half the concentration of salts of MS medium supplemented with 50mL $L^{-1}$ coconut water.

Key words: embryo culture, in vitro propagation, palm tree, Acrocomia aculeata.

\section{INTRODUÇÃO}

A crescente demanda por energia, a preocupação ambiental e a redução das reservas petrolíferas tornam imprescindível a busca por novas fontes de energia. Espécies vegetais das quais derivados lipídicos pudessem ser utilizados na produção de biodiesel, principalmente por seu caráter renovável e biodegradável, constituir-se-iam em uma alternativa viável.

Entre as várias espécies de plantas capazes de produzir matéria-prima para a produção de biodiesel, as palmeiras são consideradas as mais promissoras. A macaúba (Acrocomia aculeata (Jacq.) Lodd. Ex Martius) é uma palmeira amplamente distribuída no continente americano, incluindo o México, Antilhas, Brasil, Argentina, Uruguai e Paraguai. Diferente do dendê (Elaeis guineensis), que exige um ambiente tropical, quente e úmido para crescer, a macaúba é

'Departamento de Agricultura, Laboratório de Cultura de Tecidos Vegetais, Universidade Federal de Lavras (UFLA), 37200-000, Lavras, MG, Brasil. E-mail: joycerodrigues01@yahoo.com.br. *Autor para correspondência. 
produtiva e seus frutos podem gerar mais de $5.000 \mathrm{~kg}$ de óleo por hectare, não sendo exigente em termos climáticos (TICKEL, 2000). No entanto, plantações de macaúba no Brasil e em muitos lugares do mundo ainda estão em sua fase primária. A exploração do fruto ocorre principalmente através da coleta em grandes populações naturais (MOTTA et al., 2002).

A exploração comercial da macaúba depende do desenvolvimento de tecnologia, que inclui a seleção de clones elite e sua propagação. Genótipos superiores podem ser selecionados de populações naturais de plantas, porém, é impossível propagá-los vegetativamente através de técnicas convencionais, pois não têm meristema axilar, a produção de perfilhos está restrita a apenas algumas espécies (LEDO et al., 2001), a germinação, em condições naturais, pode demorar de um a dois anos (LORENZI, 2006). Assim, a cultura de embriões apresenta-se como ferramenta de grande valia na produção de mudas uniformes dessas espécies, pois permite, dentre outras aplicações, a produção de plantas livres de patógenos e aceleração dos programas de melhoramento.

Resultados promissores têm sido obtidos com a técnica da cultura de embriões zigóticos na propagação de muitas palmeiras, sendo representados principalmente pelo aumento das taxas de germinação, uniformidade das plantas e conversão de plântulas viáveis para espécies como Cocos nucifera (ASHBURNER et al., 1993; MOLLA et al., 2004; TZECSIMÁ et al., 2006; LEDO et al., 2007; PECH-AKÉ et al., 2007), Euterpe oleracea (LEDO et al., 2001), Syagrus oleracea (MELO et al., 2001), Mauritia flexuosa (SPERA et al., 2001), Astrocaryum ulei (PEREIRA et al., 2006) e Hyophorbe lagenicaulis (SARASAN et al., 2002).

Em detrimento ao observado para algumas espécies comerciais de palmeiras, por exemplo, Cocos nucifera (SILVA et al.,, 2002; SANTANA et al., 2003; LEDO et al., 2007) e Phoenix dactylifera (IOSSI et al., 2003), muito pouco se conhece a respeito das condições adequadas de concentração de sais e suplementação no ambiente in vitro, com vistas à obtenção de plântulas vigorosas e com maiores possibilidades de sobrevivência na fase de aclimatização.

O presente trabalho teve por objetivo avaliar diferentes concentrações de sais minerais e água de coco na germinação e crescimento inicial in vitro de plântulas de macaúba (Acrocomia aculeata) oriundas de embriões zigóticos.

\section{MATERIAL E MÉTODOS}

O trabalho foi conduzido no Laboratório de Cultura de Tecidos do Departamento de Agricultura, da Universidade Federal de Lavras, no município de Lavras, MG, onde foram utilizados como fonte de explantes, frutos maduros colhidos de cinco plantas adultas de populações naturais, existentes no município de Ijací, MG, no mês de maio de 2008. Foram coletados duzentos frutos, armazenados em caixa agrícola preta $\left(31 \times 36 \times 55 \mathrm{~cm}^{3}\right)$, conduzidos até o Laboratório de Cultura de Tecidos, os quais permaneceram em galpão à temperatura ambiente. Após 16 horas, foi removido o pericarpo dos frutos para a remoção do endocarpo e liberação da amêndoa, contendo em seu interior o embrião zigótico (Figura 1A e 1B). Estes foram retirados e desinfestados em hipoclorito de sódio comercial a $20 \%$ por 20 minutos, seguido de cinco enxágues sucessivos em água destilada e autoclavada, sendo posteriormente inoculados na posição horizontal (Figura 1C).

Os embriões foram inoculados em tubos de ensaio contendo $15 \mathrm{~mL}$ de meio de cultura MS (MURASHIGE \& SKOOG, 1962), suplementado com $100 \mathrm{mg} \mathrm{L}^{-1}$ de mio-inositol, vitaminas de $\mathrm{MS}, 3 \mathrm{~g} \mathrm{~L}^{-1} \mathrm{de}$ carvão ativado, $2 \mathrm{mg} \mathrm{L}^{-1}$ de glicina, $3 \%$ de sacarose e $6,5 \mathrm{~g} \mathrm{~L}^{-1}$ de ágar. Os tratamentos consistiram de combinações de sais do meio MS (50 e 100\%) com água de coco $\left(0,50,100\right.$ e $\left.150 \mathrm{~mL} \mathrm{~L}^{-1}\right)$, distribuídos em delineamento experimental inteiramente casualizado

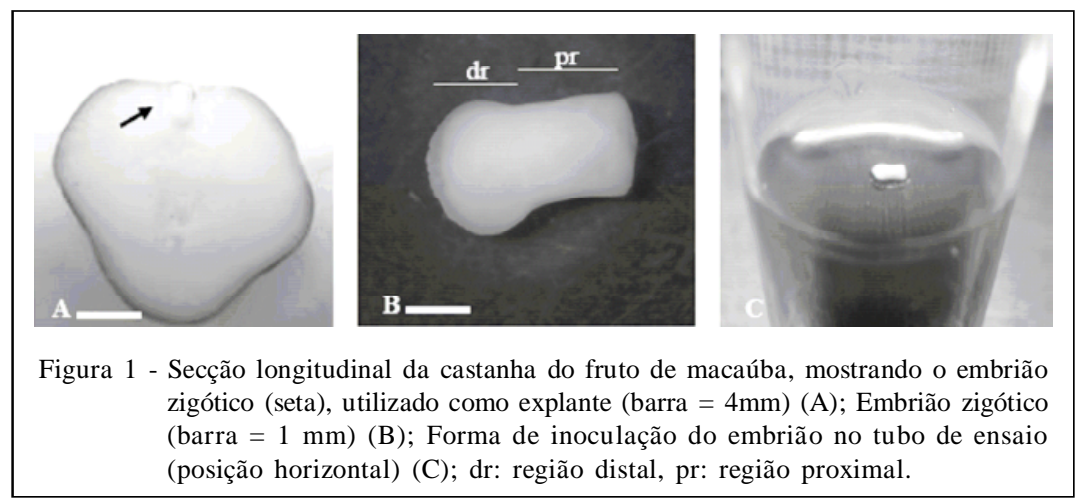

Ciência Rural, v.41, n.5, mai, 2011. 
com tratamentos fatoriais $2 \times 4$, em quatro repetições. $\mathrm{O}$ meio teve seu $\mathrm{pH}$ ajustado para $5,8 \pm 0,1$ antes do processo de autoclavagem a $121^{\circ} \mathrm{C}$ e $1 \mathrm{~atm}$. Após a inoculação, as culturas foram mantidas em sala de crescimento com temperatura de $25 \pm 2^{\circ} \mathrm{C}$ e fotoperíodo de 16 horas com intensidade luminosa de $42 \mathrm{~W} \mathrm{~m}^{-2}$.

Avaliações foram realizadas com base na porcentagem de germinação e no índice de velocidade de germinação (IVG), desde 21 dias após a instalação do experimento até sua conclusão (90 dias), contabilizando-se a cada três dias os embriões germinados. OIVG foi determinado segundo a fórmula de MAGUIRE (1962). Embriões que emitiram parte aérea e raiz foram considerados germinados. Avaliou-se também o percentual de plântulas normais e de plântulas que emitiram raízes secundárias ou apenas primórdio de raiz. Foram consideradas plântulas normais, aquelas que apresentaram expansão foliar e, esporadicamente, desenvolvimento de raízes secundárias. Plântulas com aspecto hiperídrico, com crescimento atrofiado da plúmula e da raiz primária e ausência de expansão foliar foram consideradas anormais.

Ao final de 90 dias, foram realizadas avaliações quanto ao número de raízes, comprimento médio de raízes e de parte aérea e massa fresca de plântulas. Os dados obtidos foram analisados pelo programa Sisvar (FERREIRA, 2000) a 5\% de probabilidade de erro, sem que houvesse transformação de dados.

\section{RESULTADOS E DISCUSSÃO}

Germinação de embriões zigóticos - Aos 30 dias de cultivo in vitro, havia 60,6\% de germinação e, embora já apresentasse um valor expressivo, o final do processo germinativo de embriões zigóticos de macaúba foi concluído aos 60 dias, obtendo-se uma taxa de 95,6\% da inoculação, independente da concentração do meio (Figura 2A).

Independente da concentração de água de coco e de meio MS, não houve efeito significativo sobre o índice de velocidade de germinação, porém, houve superioridade no meio MS com $100 \%$ dos sais em relação ao meio com 50\% dos sais (Figura 2B), indicando que os embriões de macaúba requerem maior quantidade de sais para germinarem. Geralmente, os embriões necessitam de elevada concentração de nutrientes para se desenvolverem, fato demonstrado pela diminuição no desenvolvimento dos embriões quando houve redução na concentração de sais do meio de cultura.

Para a variável porcentagem de plântulas normais, houve efeito significativo na interação entre os fatores. Registrou-se aumento nessa porcentagem quando se utilizou $50 \%$ do meio MS e concentração de água de coco até $50 \mathrm{~mL} \mathrm{~L}^{-1}(83 \%)$ (Figura 3A). Em concentrações superiores tanto de água de coco (100 e $150 \mathrm{~mL} \mathrm{~L}^{-1}$ ) quanto de meio MS $100 \%$, foram obtidas porcentagens de germinação em ordem decrescente (41 e 6\%; 64\% e 37\%, respectivamente).

Comportamento semelhante foi observado em relação à conversão de plântulas com emissão de raízes secundárias (Figura 3B), já que $70 \%$ destas foram obtidas na concentração de $50 \mathrm{~mL} \mathrm{~L}^{-1}$ de água de coco para o meio MS com 50\% dos sais. Provavelmente, a concentração original do meio MS aliada à suplementação com água de coco influenciou negativamente tanto a porcentagem de plântulas

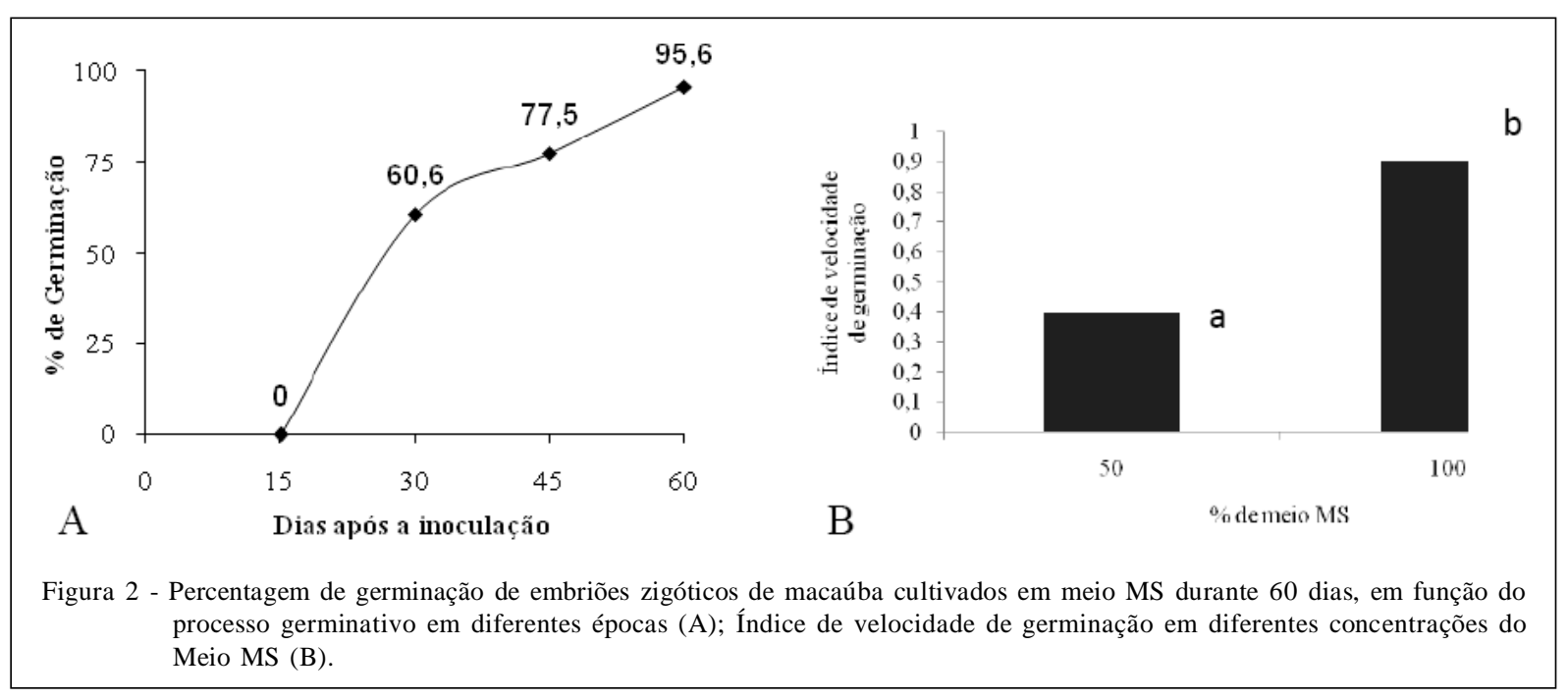

Ciência Rural, v.41, n.5, mai, 2011. 

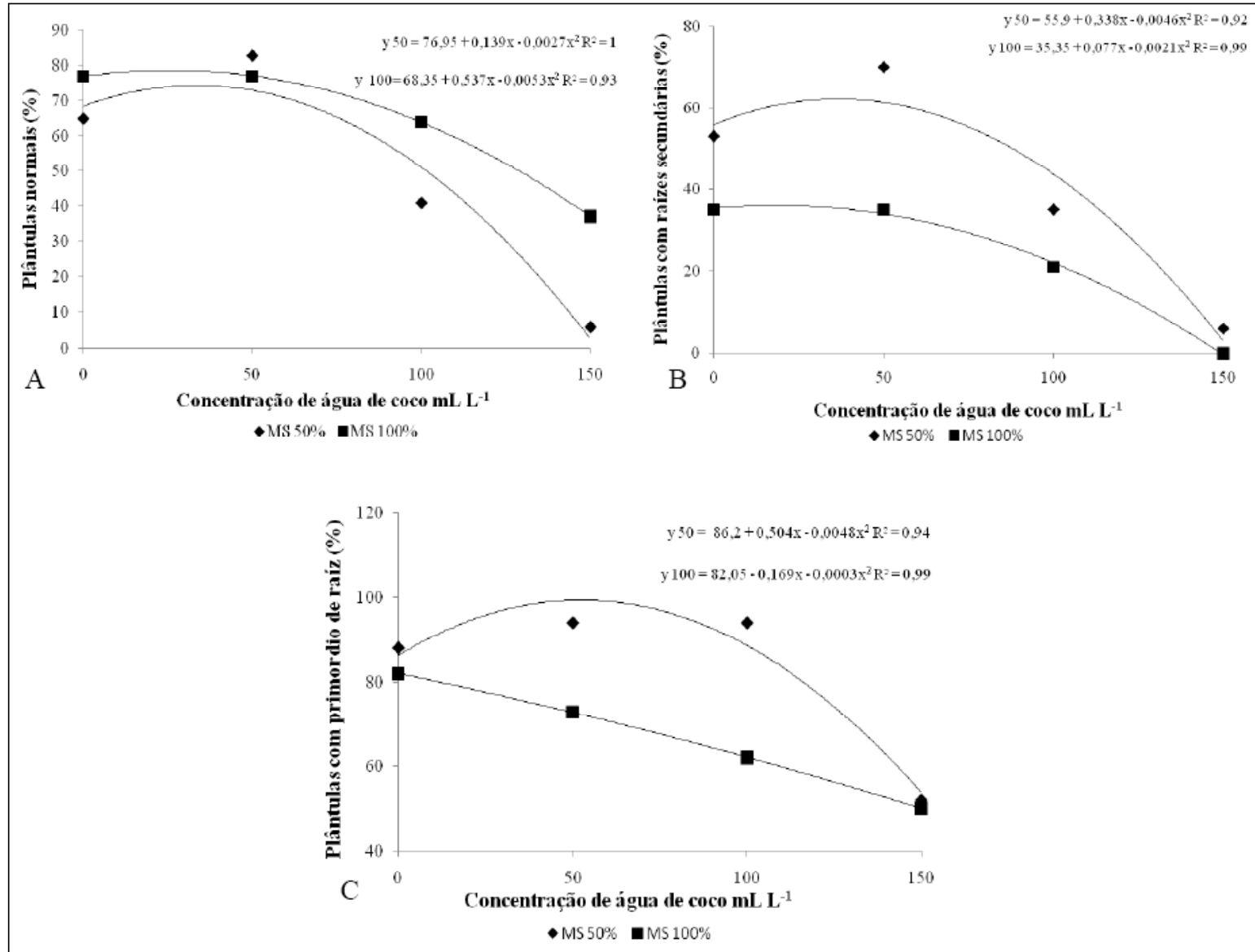

Figura 3 - Concentrações de água de coco em relação à porcentagem de: plântulas normais (A); plântulas com raízes secundárias (B); plântulas com primórdios de raiz (C) de macaúba cultivadas em meio MS nas concentrações de $50 \%$ e $100 \%$ dos sais.

normais como de plântulas com raízes secundárias. Altos percentuais de plantas com emissão de primórdios de raiz também foram observados (Figura 3C). Maiores índices (94\%) foram obtidos nas concentrações de 50 e $100 \mathrm{~mL} \mathrm{~L}^{-1}$ de água de coco e metade da formulação do meio MS. Em relação a $100 \%$ do meio MS, melhores resultados foram obtidos na ausência de água de coco com consequente redução dos primórdios de raiz, à medida que se aumentaram as concentrações de água de coco.

Após a fase de germinação, as plântulas de macaúba mostraram requerer menor quantidade de nutrientes quando comparado à formulação completa do meio MS para as variáveis analisadas, o que está de acordo com MALAVOLTA (2006), que diz que todo nutriente em excesso, provoca um desbalanço nutricional no sistema, que consequentemente provoca prejuízos no desenvolvimento da plântula.

Crescimento inicial de plântulas - Houve interação significativa em todas as variáveis estudadas: número de raiz, comprimento da maior raiz, comprimento da parte aérea e massa fresca de plântulas.

Maior número de raízes $(3,82)$ foi obtido com a concentração de $50 \%$ de meio de cultura e na ausência de água de coco (Figura 4A). Em relação à concentração original dos sais, verificou-se acréscimo de forma quadrática no número de raízes $(3,12)$ até a concentração de $50 \mathrm{~mL} \mathrm{~L}^{-1}$ de água de coco. Esses resultados discordam dos obtidos por ARAUJO et al. (2006) que, trabalhando com orquídea, obtiveram maiores resultados para número de raízes com a utilização de $50 \mathrm{~mL} \mathrm{~L}^{-1}$ de água de coco combinado com $100 \mathrm{~g} \mathrm{~L}^{-1} \mathrm{de}$ polpa de banana. $\mathrm{O}$ aumento na quantidade de raízes formadas in vitro possibilita maior superfície de contato raiz/substrato, refletindo em maior absorção dos nutrientes, o que foi possível por meio de uma maior concentração de sais em plântulas de macaúba, sem a necessidade de adição de água de coco.

Melhores resultados para comprimento médio de raízes em plântulas de macaúba foram 

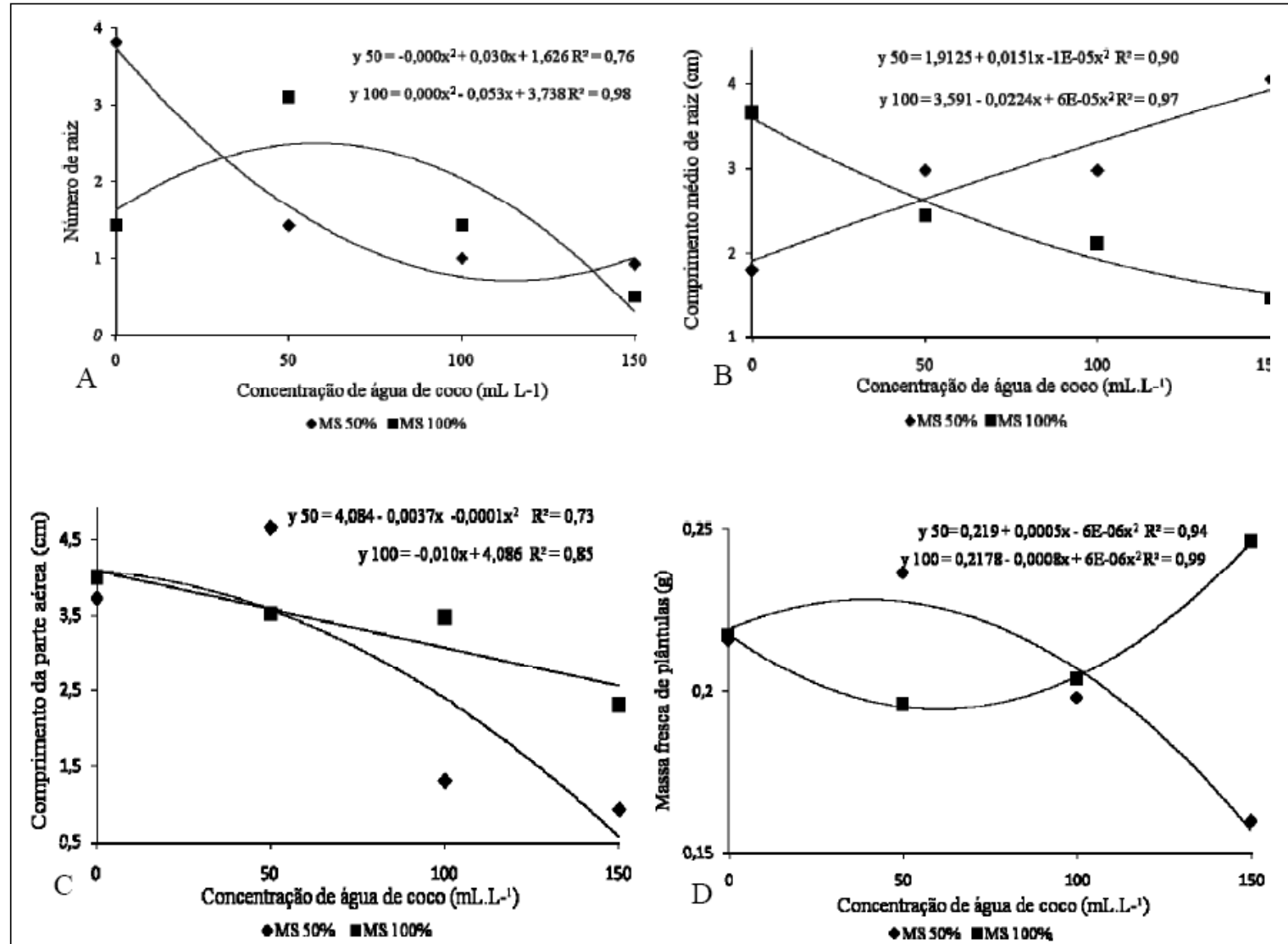

Figura 4 - Concentrações de água de coco no número de raízes (A); comprimento de raiz (B); comprimento da parte aérea (C) e massa fresca de plântulas (D) de macaúba cultivadas em meio MS nas concentrações de $50 \%$ e $100 \%$ dos sais.

observados com metade do meio MS acrescidos de $150 \mathrm{ml} \mathrm{L}^{-1}$ de água de coco (Figura 4B). Com incremento nas concentrações de água de coco em presença de $50 \%$ de meio MS, obteve-se maior comprimento de raiz $(4,05 \mathrm{~cm})$.

Maiores resultados para o comprimento da parte aérea $(4,66 \mathrm{~cm})$ foram obtidos com a utilização de $50 \mathrm{~mL} \mathrm{~L}^{-1}$ de água de coco e $50 \%$ de meio MS (Figura 4C). A partir desse ponto, houve decréscimo de forma quadrática, que também foi observado no meio com concentração original, sendo que maiores resultados foram obtidos na ausência de água de coco.

Observa-se na figura 4D que o aumento das concentrações de água de coco, no meio original, proporcionou decréscimo de forma quadrática na massa fresca de plântulas até $59,0 \mathrm{~mL} \mathrm{~L}^{-1} \mathrm{e}$, a partir desse ponto, houve incremento em massa $(0,24 \mathrm{~g})$ até a concentração de $150 \mathrm{~mL} \mathrm{~L}^{-1}$ de água de coco. No meio com metade da concentração dos sais, obteve-se acréscimo na massa fresca $(0,23 \mathrm{~g})$ de forma quadrática até a concentração de $42,0 \mathrm{~mL} \mathrm{~L}^{-1}$ de água de coco, a partir da qual houve decréscimo. Esses resultados concordam com FERREIRA et al. (2002) e ARAUJO et al. (2006) que, estudando micropropagação de cupuaçu e orquídeas, respectivamente, obtiveram melhores resultados para massa fresca de plântulas com a utilização de meio MS 100\% e altas concentrações de água de coco $\left(200 \mathrm{~mL} \mathrm{~L}^{-1}\right)$.

De modo geral, a capacidade tamponante dos meios nutritivos é baixa, o que dificultaria a absorção de nutrientes. O acréscimo de água de coco, por sua vez, aumenta essa capacidade tamponante (ARAUJO et al., 2006), sendo, provavelmente, uma das causas da maior produção de massa fresca. Outro importante fator para explicar os resultados seria a presença de aminoácidos e citocininas na água de coco (SILVA et al., 2002).

\section{CONCLUSÃO}

Maior porcentagem de germinação de embriões de macaúba é obtida aos 60 dias, em meio MS, independente da concentração dos sais.

Após a germinação, as plântulas devem ser repicadas para meio $\operatorname{com} 1 \frac{3}{2}$ da concentração de sais do $\mathrm{MS}+50 \mathrm{~mL} \mathrm{~L}^{-1}$ de água de coco. 


\section{REFERÊNCIAS}

ARAUJO, A.G. et al. Água de coco e polpa de banana no cultivo in vitro de plântulas de orquídea. Revista Ceres, v.53, p.608$613,2006$.

ASHBURNER, G.R. et al. Effect of a-naphthaleneacetic acid and sucrose levels on the development of cultured embryos of coconut. Plant Cell, Tissue and Organ Culture, v.35, p.157163, 1993. Disponível em: <http://www.springerlink.com/ content/rp21186463278448/>. Acesso em: 14 fev. 2011. doi: 10.1007/BF00032965.

FERREIRA, D.F. SISVAR 4.3: Sistema de análise estatística. Lavras: UFLA/DEX, 2000. Software.

FERREIRA, M.G.R. et al. Resposta de eixos embrionários de cupuaçu (Theobroma grandiflorum Schum.) à concentração de sais, doses de sacarose e renovação do meio de cultivo. Revista Brasileira de Fruticultura, v.24, n.1, p.246-248, 2002. Disponível em: <http://www.scielo.br/scielo.php?pid=S0100$29452002000100053 \&$ script $=$ sci_abstract $\&$ tlng $=p t>$. Acesso em: 9 out. de 2010. doi: 10.1590/S0100-29452002000100053.

IOSSI, E. et al. Efeitos de substratos e temperaturas na germinação de sementes de tamareira-anã (Phoenix roebelenii O'Brien). Revista Brasileira de Sementes, v.25, n.2, p.63-69, 2003. Disponível em: <http://www.scielo.br/scielo.php?pid=S0101$31222003000400009 \&$ script $=$ sci_abstract $\&$ tlng $=p t>$. Acesso em: 09 out. de 2010. doi: 10.1590/S0101-31222003000400009.

LEDO, A.S. et al. Cultivo in vitro de embriões zigóticos e aclimatação de plântulas de coqueiro-anão. Pesquisa Agropecuária Brasileira, v.42, n.2, p.147-154, 2007. Disponível em: <http://www.scielo.br/scielo.php?pid=S0100$204 X 2007000200002 \&$ script $=$ sci_abstract\&tlng $=p t>$. Acesso em: 09 out. 2010. doi: 10.1590/S0100-204X2007000200002.

LEDO, A.S. et al. Cultura in vitro de embriões zigóticos de açaizeiro. Revista Brasileira de Fruticultura, v.23, n.3, p.468-472, 2001. Disponível em: <http://www.scielo.br/scielo. php?pid=S0100$29452001000300003 \&$ script $=$ sci_abstract $\&$ tlng $=p t>$. Acesso em: 09 de out. 2010. doi: 10.1590/S0100-29452001000300003.

LORENZI, G.M.A.C. Acrocomia aculeata (Jacq.) Lodd ex Mart - Arecaceae: bases para o extrativismo sustentável. 2006. 156f. Tese (Doutorado em Produção Vegetal) Universidade Federal do Paraná, PR.

MAGUIRE, J.B. Speed of germination-aid in selection and evaluation for seedling emergence vigor. Crop Science, v.2, p.176-177, 1962.

MALAVOLTA, E. Manual de nutrição mineral de plantas. Piracicaba: POTAFOS, 2006. 638p.

MELO, B. et al. Diferentes antioxidantes no controle da oxidação, germinação e desenvolvimento das plântulas na cultura in vitro de embriões da guarirobeira (Syagrus oleracea (Mart.) Becc). Ciência e Agrotecnologia, v.25, p.13011306, 2001.

MOLLA, M.M.H. et al. In vitro coconut (Cocos nucifera L.) embryo culture in Bangladesh. Biotechnology, v.3, p.98-101, 2004.
MOTTA, P.E. et al. Ocorrência da macaúba em Minas Gerais: relação com atributos climáticos, pedológicos e vegetacionais. Pesquisa Agropecuária Brasileira, v.37, p.1023-1031, 2002. Disponível em: <http://www.scielo.br/scielo.php?pid=S0100$204 X 2002000700017 \&$ script $=$ sci_abstract $\&$ tlng $=p t>$. Acesso em: 09 de out. 2010. doi: 10.1590/S0100-204X2002000700017.

MURASHIGE, T.; SKOOG, F. A revised medium for rapid growth and bioassays with tobacco tissue cultures. Physiologia Plantarum, v.15, p.473-479, 1962. Disponível em: <http:// onlinelibrary.wiley.com/doi/10.1111/j.13993054.1962.tb08052.x/abstract>. Acesso em: 14 fev 2011. doi: $10.1111 / \mathrm{j} .1399-3054.1962 . t b 08052 . x$

PECH-AKÉ, A. et al. The effect of gibberellic acid on the in vitro germination of coconut zygotic embryos and their conversion into plantlets. In Vitro Cellular and Developmental BiologyPlant, v.43, p.247-253, 2007. Disponível em: <http:// www.springerlink.com/ content $/ 67 \mathrm{~m} 7327 \mathrm{hm} 479553 \mathrm{~g} />$. Acesso em: 14 fev. 2011. doi: 10.1007/s11627-006-9018-1.

PEREIRA, J.E.S. et al. Germinação in vitro de embriões zigóticos de murmuru (Astrocaryum ulei). Ciência e Agrotecnologia, v.30, n.2, p.251-256, 2006. Disponível em: <http://www.scielo.br/scielo.php?pid=S 1413 $70542006000200009 \&$ script $=$ sci_abstract\&tlng $=$ pt $>$. Acesso em: 09 out. 2010 . doi: 10.1590/S1413-70542006000200009.

SANTANA, M.C. et al. Efeito da temperatura sobre a germinação in vitro de embriões zigóticos de Cocos nucifera L. (Arecaceae). Biologia Geral e Experimental, v.3, n.2, p.41-46, 2003. Disponível em: <http://www.biologiageralexperimental.bio.br/ edicoes/41-46.pdf>. Acesso em 14 fev. 2011.

SARASAN, V. et al. In vitro germination and induction of direct somatic embryogenesis in "Bottle Palm" (Hyophorbe lagenicaulis L. Bailey H. E. Moore), a critically endangered mauritian palm. Plant Cell Reports, v.20, p.1107-1111, 2002. Disponível em: <http://www.springerlink.com/content/ n5ux6em3tatrmjly/>. Acesso em: 14 fev. 2011. doi: 10.1007/ s00299-002-0454-z.

SPERA, M.R.N. et al. Quebra de dormência, viabilidade e conservação de sementes de buriti (Mauritia flexuosa). Pesquisa Agropecuária Brasileira, v.36, n.12 p.1567-1572, 2001. Disponível em: <http://www.scielo.br/scielo.php?pid=S0100204X2001001200015\&script=sci_abstract\&tlng=pt $>$. Acesso em: 09 de out. 2010. doi: 10.1590/S0100-204X2001001200015.

SILVA, A.L.L. et al. Efeitos de alguns meios de cultura sobre o desenvolvimento in vitro de Cattleya tigrina A. Rich. Ex Beer Orchidaceae. Curitiba: ABCTP Notícias, 2002. 102 p.

TICKEL, J. From the fryer to the fuel tank: the complete guide to using vegetable oil as an alternative fuel. Tallahassee, FL: Tickel Energy Consulting, 2000. 155 p.

TZEC-SIMÁ, M.A. et al. In vitro rescue of isolated embryos of Bactris major Jacq. and Desmoncus orthacanthos Mart., potentially useful native palms from the Yucatan peninsula (Mexico). In Vitro Cellular and Developmental BiologyPlant, v.42, p.54-58, 2006. Disponível em: <http:// www.springerlink.com/content/b15607857r65658n/>. Acesso em: 14 fev. 2011. doi: 10.1079/IVP2005715. 